Residence, Clifton Hill House. Inquiries should be addressed to the Director of the Department of Adult Education, W. E. Salt, University, Bristol 8; completed application forms should be returned by June 15 .

\section{Summer School in Metal Physics}

A Summer School in Metal Physies will be held in the Cavendish Laboratory, Cambridge, during August 23-September 3. The School will provide an introduction to the application of physical methods to the examination and utilization of metals, and is intended for those whose researches require a more fundamentally physical approach than is usual in ordinary metallurgical and engineering practice. The lectures and demonstrations will deal with $(a)$ application of X-ray methods in the examination of metals, (b) physical and mechanical properties of metals. Both parts will be taken by all attending the School, and for Part $(\alpha)$ an elementary knowledge of X-ray diffraction methods and of crystal symmetry will be assumed. A detailed syllabus and form of application for admission can be obtained from G. F. Hickson, Secretary of the Board of Extra-Mural Studies, Stuart House, Cambridge, to whom the completed application form should be returned not later than June 1.

\section{University of London: Appointments}

THE following appointments in the University of London have been announced: Prof. A. C. Offord, professor of mathematics at King's College, Newcastle-upon-Tyne, since 1945, to the University chair of mathematics tenable at Birkbeck College as from October 1; Dr. R. E. M. Wheeler, director-general of archæology in India since 1944, to the chair of the archæology of the Roman Provinces tenable at the Institute of Archæology as from October 1; Miss Mary Barber, lecturer in bacteriology in the British Postgraduate Medical School, to the University readership in bacteriology tenable at St. Thomas's Hospital Medical School as from October 1; Dr. H. E. Rose, lecturer in mechanical engineering at King's College, to the University readership in mechanical engineering tenable at the College as from October 1 .

The following titles have been conferred : professor of geology in the University on Dr. Leonard Hawkes (Bedford College); reader in organic chemistry in the University on Dr. A. H. Cook (Imperial College of Science and Technology); reader in chemistry in the University on Dr. H. G. Poole (University College); reader in agricultural chemistry in the University on Dr. R. L. Wain (Wye College).

The degree of D.Sc. has been conferred on Franz Bergel (Lister Institute of Preventive Medicine).

\section{Colonial Service Appointments}

THE following appointments in the Colonial Service have been announced: J. L. Fleure, survey probationer, Malaya; R. W. Butler, veterinary officer, Tanganyika; R. M. S. Neave, veterinary officer, Kenya; D. Bradwell, analyst, Medical Department, Cyprus; R. L. Hartley, agricultural education officer, Fiji ; C. W. D. Kermode, assistant conservator of forests, Tanganyika; J. P. Oliver, agricultural officer, Falkland Islands ; L. Ross, assistant meteoro. logist, Nigeria ; A. J. Willis, assistant meteorologist, Nigeria; E. W. Leach (deputy director of agriculture, Trinidad), director of agriculture, Trinidad; J. C. Muir (director of agriculture, Trinidad), director of agriculture, Tanganyika; F. W. Toovey (principal research officer, Oil Palm Research Station, Nigeria), officer-in-charge, Oil Palm Research Station, Nigeria; H. Fraser (assistant conservator of forests, Tanganyika), senior assistant conservator of forests, Tanganyika; H. R. Herring (assistant conservator of forests, Tanganyika), senior assistant conservator of forests, Tanganyika; A. L. C. Thorne (veterinary officer, Gold Coast), veterinary education officer, Nigeria; J. Y. Moggridge (entomologist, Tsetse Research Department, Tanganyika), director, Tsetse Research Control Department, Tanganyika; H. C. Smith (senior assistant livestock officer, Tanganyika), livestock officer, Tanganyika; J. F. B. Watling (senior inspector of produce, Nigeria), principal produce inspector, Nigeria.

\section{New Satellite of Uranus}

IT is reported from the McDonald Observatory, Texas, that a new satellite of magnitude 17 to the planet Uranus was found on a plate taken on February 15, at the Cassegrain focus of the 82 -in. telescope. Two other plates taken on March 1 confirmed the new discovery. Its distance from the planet is about 0.00082 astronomical unit, or 76,500 miles, which implies that its period of revolution is about 31 hours.

\section{Acetylation of Sugars}

ReFerRiNe to the communication by S. D. Nicholas and Dr. F. Smith entitled "Acetylation of Sugars" (Nature, March 6, p. 349), Dr. P. H. Plesch, Chemistry Department, University of Manchester, remarks that the use of perchloric acid as catalyst in the acetylation of sugars is by no means new ; it has been discussed in some detail by D. Krueger and W. Roman (Berichte, 69, 1830 (1936) and Angew. Chem., 47, 58 (1934)).

\section{Announcements}

Mr. NorRIs E. DodD, Under-Secretary of Agriculture in the United States, has been appointed director-general of the United Nations Food and Agriculture Organisation, in succession to Sir John Boyd Orr, who has retired. The British Minister of Food has agreed to release Sir Herbert Broadley, deputy secretary, Ministry of Food, for appointment as deputy director general of the Organisation.

THE Fison Lectures of the Animal Health Trust will be delivered by Prof. L. Seekles, of the Veterinary Biochemical School of the University of Utrecht, at the Kingsway Hall, London, on May 10 and 12. He will discuss mineral disturbances in cattle, gastrointestinal autointoxication in cattle and horses, and conditional deficiencies of trace elements in cattle. Further particulars may be obtained from the Animal Health Trust, 232-235 Abbey House, Victoria Street, London, S.W.I.

The Ministry of Agriculture and Fisheries and the Department of Agriculture for Scotland propose to award, for the next academic year, a limited number of postgraduate scholarships in husbandry, agricultural economics, statistics and agricultural and dairy engineering. Particulars may be obtained from the Secretary, Ministry of Agriculture and Fisheries, 2 Cambridge Terrace, Regent's Park, London, N.W.1, or the Secretary, Department of Agriculture for Scotland, St. Andrew's House, Edinburgh 1.

Erratum. In the note on "American Summer Scholarships for European Students" (Nature, April 17, p. 593), it should have been stated that applicants must be less than thirty-five years of age. 